\title{
Article \\ Stakeholders' Perception of the Impact of the Declaration of New Protected Areas on the Development of the Regions Concerned, Case Study: Czech Republic
}

\author{
Jiří Schneider, Aleš Ruda *(D) and Martina Blahová
}

check for updates

Citation: Schneider, J.; Ruda, A.; Blahová, M. Stakeholders' Perception of the Impact of the Declaration of New Protected Areas on the Development of the Regions Concerned, Case Study: Czech Republic. Forests 2021, 12, 580. https://doi.org/10.3390/f12050580

Academic Editors: Juan

F. Fernández-Manjarrés and Roxane Sansilvestri

Received: 22 March 2021 Accepted: 28 April 2021 Published: 6 May 2021

Publisher's Note: MDPI stays neutral with regard to jurisdictional claims in published maps and institutional affiliations.

Copyright: (c) 2021 by the authors. Licensee MDPI, Basel, Switzerland. This article is an open access article distributed under the terms and conditions of the Creative Commons Attribution (CC BY) license (https:// creativecommons.org/licenses/by/ $4.0 /)$.
Department of Environmentalistics and Natural Resources, Faculty of Regional Development and International Studies, Mendel University in Brno, tř. Gen. Píky 7, 61300 Brno, Czech Republic; jiri.schneider@mendelu.cz (J.S.); zaneta.kalasova@mendelu.cz (M.B.)

* Correspondence: ales.ruda@mendelu.cz; Tel.: +420-545-136-252

\begin{abstract}
Floodplain forests at the confluence of the rivers Dyje and Morava (in the southeastern tip of the Czech Republic) are completely unique ecosystems in terms of area and ecology. For many years, there has been an effort by the state's nature protection officials to declare the area as a Protected Landscape Area. This effort is met by the resistance of foresters and other local stakeholders. The study focuses on the identification of stakeholders' comments and objections to the planned declaration of the Soutok PLA and the comparison between the objections raised and the attitudes of stakeholders from existing PLAs. Using the content analysis of 247 paper documents, the first part of the study determines the negative arguments that are subsequently verified in the second part on the basis of 17 semistructured standardized interviews and interview surveys of 200 respondents. The analysis of the interviews and surveys was based on the grounded theory method. The theoretical sampling and snowball techniques were used to recruit the respondents. The interviews and surveys showed that most concerns over restrictions established by the conservation status are unnecessary since experience showed that they are either not registered or not established by the PLA status, and their application is provided by other legislative standards.
\end{abstract}

Keywords: protected areas establishment; stakeholder participation; landscape protection; qualitative research; Soutok Protected Landscape Area (Czech Republic)

\section{Introduction}

Human activities, including agriculture, forestry, and urbanization, have influenced ecosystems to such an extent that there is only a small number of natural places in the world left [1]. As a result, protected areas are considered crucial for nature conservation [2] and the maintenance of biodiversity. The protection of natural areas is presented as a useful tool for many reasons, the most important being provisioning, regulating, cultural, and supporting ecosystem services [3,4].

Protected Landscape Areas (PLAs) are one of the categories of protected areas (PAs) according to Act 114/1992 Coll. on nature and landscape protection. PLAs are defined as large areas with a harmoniously shaped landscape, characteristic relief, a significant proportion of natural forest ecosystems, and permanent grasslands. The economic use is carried out according to the zones of graded protection so that their natural state is maintained and improved, and the optimal ecological functions of these areas are preserved or recreated. The protection regime is therefore looser here than in the case of national parks.

Social support is one of the key factors that determine the successful establishment and management of protected areas [5-8]. The perception of a Protected Landscape Area (PLA) in designation could differ from the perception of an existing Protected Landscape Area (PLA), which has been operating for years, where perception is influenced by experiences with management. Only a few studies explored perceptions before the establishment of 
PLAs $[9,10]$ even though knowledge about them is actually most important for the success of PLA establishment [11].

Currently, nature and landscape protection are much-debated issues, especially in the context of regional development. Declaration of large-size protected areas often leads to controversial and emotional debates. The authors highlighted three reasons why designated areas may not reflect public perceptions. These include the following reasonings: (i) designated landscapes may be based on historical decisions made before participatory processes were included; (ii) expert knowledge is often the only form of knowledge considered or tends to be privileged over other forms of knowledge; and (iii) the focus has been on certain landscape evaluation criteria over others (e.g., recreational, therapeutic, and spiritual values, sense of place or scenic qualities) [12]. While conservation strategies typically account for changing forest ecology, wildlife populations, and biophysical conditions, far less consideration is given to the changing perceptions of PLA neighbors [13,14].

On the other hand, in many cases, conservation activities have resulted in positive impacts for local communities, including livelihood provision through tourism development, economic benefits, environmental management, participation in governance, and the protection of historic sites and cultural resources [15-17]. If the set of management actions lived up to people's expectations, protected areas would have a higher probability of being socially supported, which must be a central point in their adaptive management [8]. The attractiveness of the preserved state of nature and landscape, which is in the long term guaranteed by the status of the protected area, is undoubtedly one of the important prerequisites for the long-term economic prosperity of local municipalities and subregions.

Rather than simply labeling conservation as positive or negative, actions taken to protect or manage the environment can produce a suite of both positive and negative impacts that variably affect social, economic, cultural, health, and governance spheres of local communities [17]. Conservation strategies are currently evolving from wilderness protection and restoration to the appropriate use of natural resources and maintenance of landscapes influenced by human management [18]. According to Bennett [19], local people's perceptions about conservation in PAs can be categorized into four thematic areas: social impacts of conservation, ecological outcomes of conservation, legitimacy of conservation governance, and acceptability of conservation management. This kind of categorization could be helpful in identifying aspects of conservation policies and management actions that are acceptable or unacceptable to local people [20].

Perception and attitudes toward protected areas establish the degree of success when it comes to sustainable conservation planning [21] because conservation initiatives require the active participation of local communities in decision-making processes and solutions to integrate local development with environmental conservation [21]. Local community involvement in the management of protected areas usually leads to increased awareness of the benefits of biodiversity, more responsible use of resources, and welfare of local people [22].

In the past decades, there has been a shift in the perception of protected areas in post-communist countries. The conventional method (officially ordered nature conservation without the acceptance of stakeholders' opinion) is abandoned and the participatory method of nature and landscape conservation is becoming the center of attention [11]. In contemporary literature, local residents' perceptions and attitudes toward protected areas are identified as key factors for the successful management of these areas [23]. According to Nastran [11], the main factors influencing the stakeholders' attitude to future protected areas are the perception of benefits, effects and costs, the possibility to participate in important meetings about the protected area, and personal experience with previous negotiations with nature conservation authorities. According to Winter et al. [10], the perception of protected areas is further influenced by socioeconomic factors (age, sex, education, ethnic origin, place of residence, etc.). Trakolis [24] stated that it is necessary to consider the divergence of opinions and the perception of benefits of the protected area between stakeholders and administrators (founders). Allendorf et al. [25] also pointed out that some one-off or past actions are quickly forgotten by stakeholders (mainly infrastructure projects and 
increased employment in services). Such a situation when people forget that protected areas generate benefits given by ecosystem services significantly contributes to the rather negative perception of protected areas [26]. The existing problems with the protection of nature highlight the need for a transdisciplinary approach. Natural areas can no longer be protected by normative regulations in situ but social factors that strongly influence the success of declaring a protected area have to be included [11].

In addition to specially protected areas, much attention has recently been paid to the perception of stakeholders at Natura 2000. It is also well known in the Soutok area. Apostolopoulou et al. [27] carried out an analysis of the participatory process in the management of the Greek Natura 2000 sites, while Rojas-Briales [28] investigated the key socioeconomic issues in the implementation of the Natura 2000 network in Spain or Nastran, and Pirnat [29] showed the stakeholder involvement in the designation of the Natura 2000 sites in Slovenia [30].

The main objective of the study is to determine the stakeholders' negative attitude factors against the declaration of the Soutok PLA and to verify the adequacy of the arguments raised by the stakeholders (representatives of local authorities, the public, interested and professional organizations), which were used as a negative stance against the declaration of the Soutok PLA. During the research, we tested the following working hypothesis: Stakeholders prevent the emergence of PLAs from irrational fears and stereotypes, or ignorance (and generally insufficient environmental education and awareness in the Czech Republic) or from their own selfish interests. Most, (in fact) almost all, of their arguments are unfounded.

\section{Materials and Methods}

\subsection{Study Area}

The Czech Republic is a landlocked hilly plateau surrounded by relatively low mountains, including the Carpathian, Ore, Sudetic, and the Sumava mountains, and lies in the temperate climate zone with average temperatures varying among the various regions of the Czech Republic; it is also characterized by mild and humid summers with occasional hot spells, and cold, cloudy, and humid winters. The Soutok (confluence, in English) area (Figure 1) is a unique landscape in the downstream parts of the Morava and Dyje rivers [31] with a mosaic of forest, meadow, wetland, and water ecosystems, with a large complex of lowland floodplain forests and part of unique historical landscaping in the Lednice-Valtice Area (UNESCO World Heritage Site and also part of UNESCO Biosphere reserve Dolní Morava). A substantial part has the character of primeval stands that, together with other types of biotopes, form an indivisible complex (Figures 2-7). The area is also extremely important for the size and quality of meadow habitats, especially continental flooded meadows. The Ministry of the Environment of the Czech Republic demarcated the Soutok PLA into two discontinuous blocks with a total area of $139 \mathrm{~km}^{2}$, separated by the town of Břeclav. The V-shaped area spreads along the Morava and Dyje rivers starting at their upstream confluence. The PLA extends to the cadastral territories of 19 municipalities in the districts of Břeclav and Hodonín. Both districts are border regions that are developing cooperation with the municipalities of Lower Austria and western Slovakia, especially in the construction of transport infrastructure and environmental protection. The area is defined and delineated so that it does not extend to the built-up parts of the municipalities.

The existing protected landscape areas of Moravský Kras/Moravian Karst and Pálava/Pavlov Highlands (Figure 1) were chosen to verify the stakeholders' arguments against the declaration of the Soutok Protected Landscape Area. Both territories are located in the South Moravian Region. Moravský Kras/Moravian Karst was declared a Protected Landscape Area in 1956 as the second PLA in the territory of the present-day Czech Republic. Pálava/Pavlov was declared a Protected Landscape Area in 1967.

Moravský Kras (Moravian Karst) is a 3 to $6 \mathrm{~km}$ wide and $25 \mathrm{~km}$ long strip of Devonian limestone [32]. The long-term goal of nature and landscape protection in the PLA is to preserve the unique set of surface and underground karst phenomena as the basis of the 
typical landscape character [33]. The Moravian Karst was declared a PLA covering an area of $92 \mathrm{~km}^{2}$ as early as 1956, which made it the second oldest PLA in the present-day Czech Republic. The value of the area was reflected in the high representation of the most strictly protected sites. Zone 1 occupies $17.7 \%$ of the PLA area.
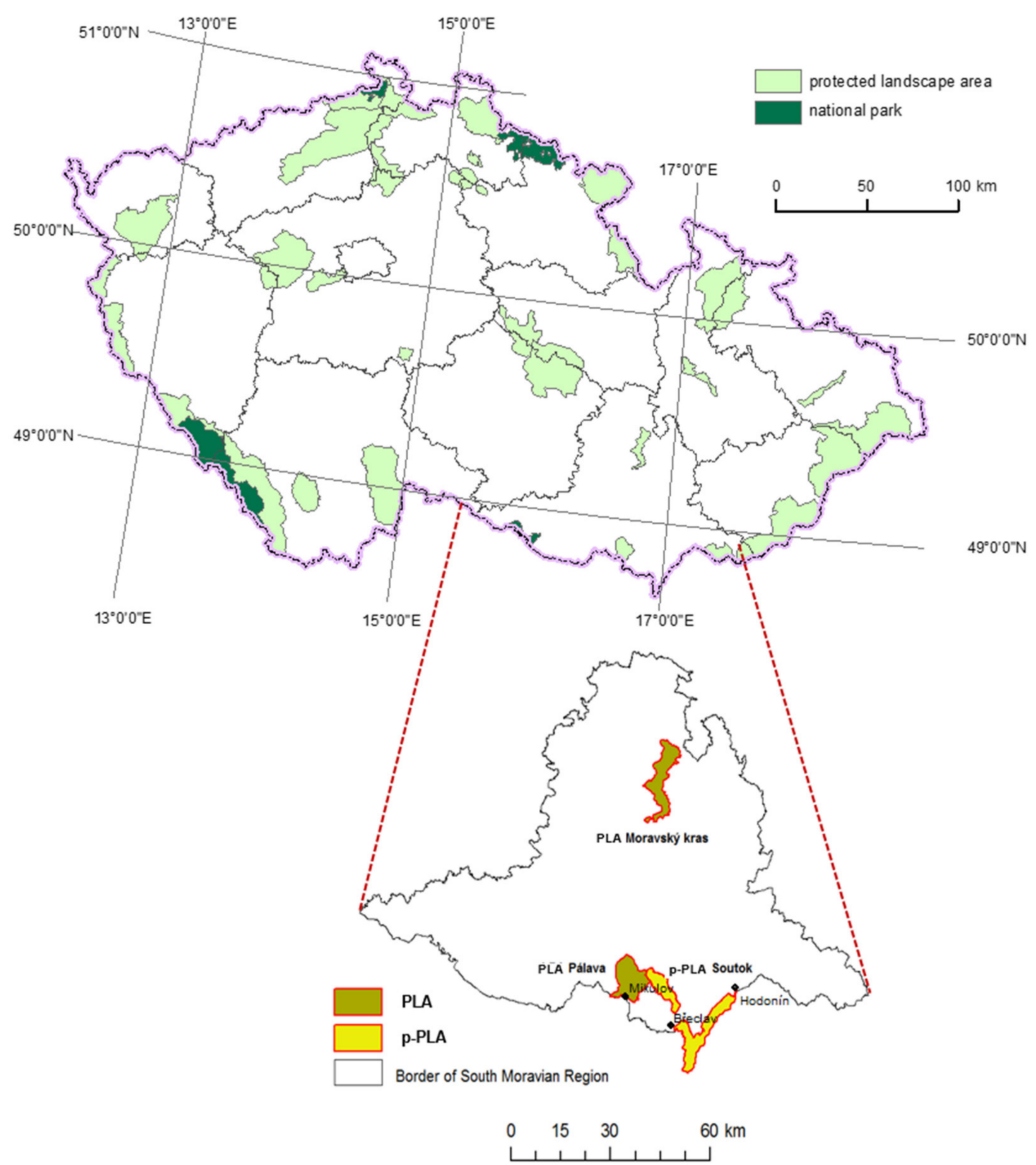

Figure 1. Study area (p-PLA planned protected landscape area). 


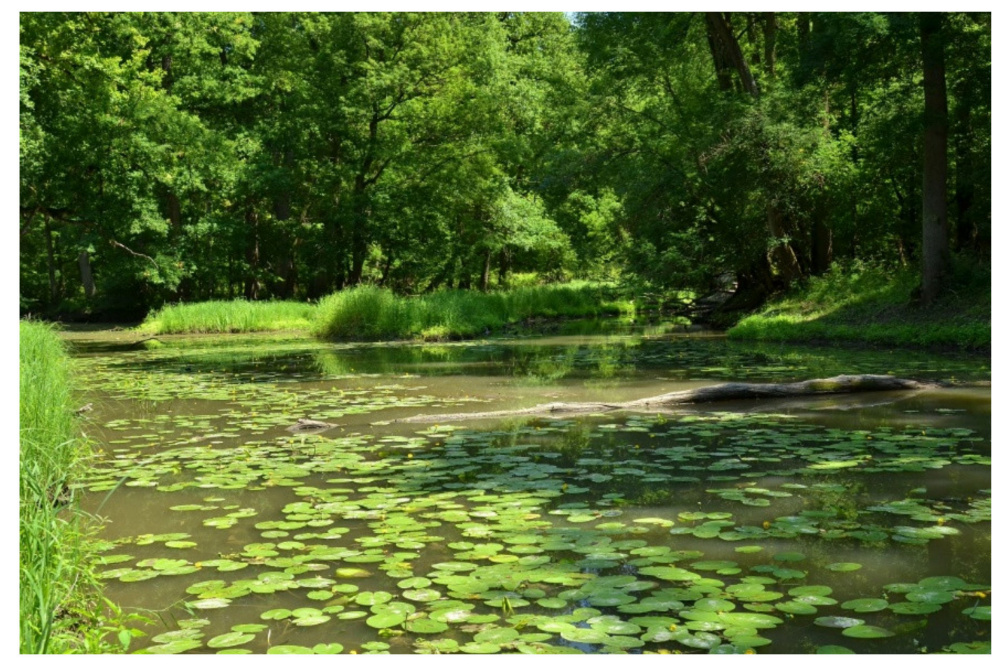

Figure 2. The floodplain forests in the Soutok area are interwoven with a network of river branches, billabongs, canals, etc.

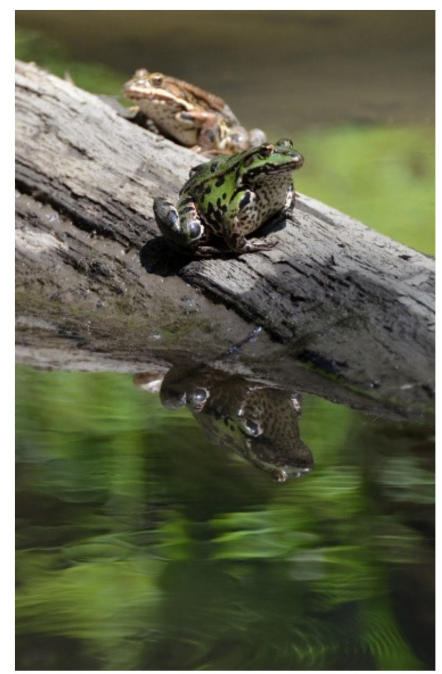

Figure 3. Which are the habitats of many specially protected plants and animals (e.g., Rana sp.).

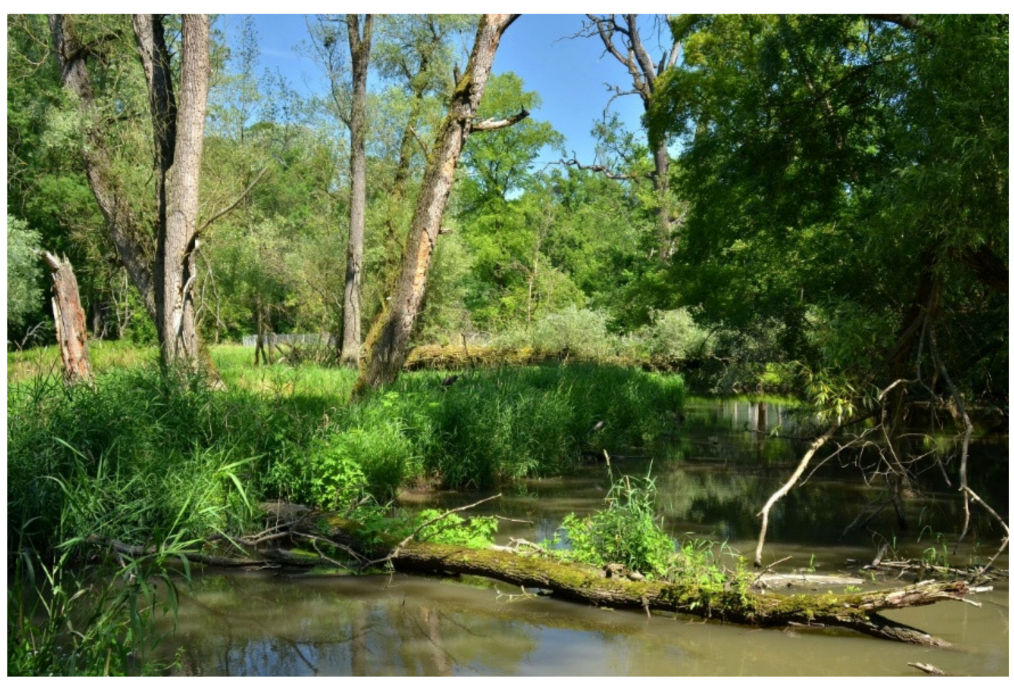

Figure 4. The mosaic of floodplain habitats is also cocreated by Willow-poplar forests of lowland rivers, tall-sedge beds, Eutrophic vegetation of muddy substrates, etc. 


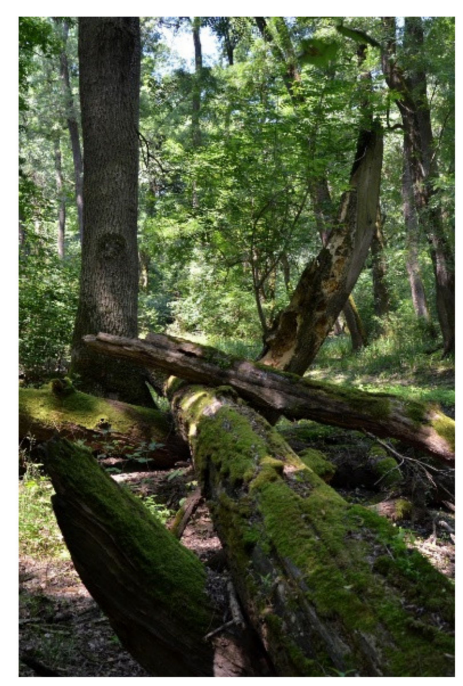

Figure 5. The most valuable parts are of primeval character with a lot of woody debris.

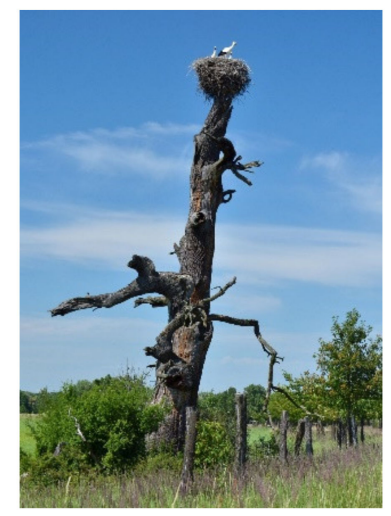

Figure 6. In addition to forests, the landscape of Soutok is formed by Continental inundated meadows with solitaires of living or dead trees, the niches of which are inhabited by specially protected animal species (e.g., white stork).

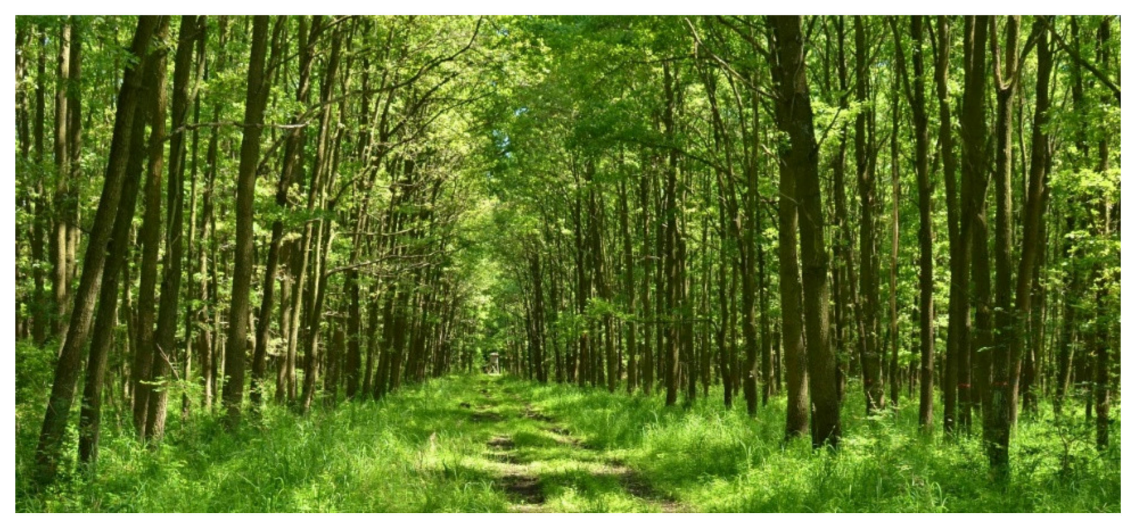

Figure 7. The result of the clear-felling system of forest management is even-aged and monocultural stands of deciduous, mostly autochthonous, tree species (oak, ash).

The area of the Protected Landscape Area Moravský Kras is located in cadastral areas of 24 municipalities. However, only the cadastral areas of the municipalities of Ostrov u Macochy and Rudice overlap completely with this protected landscape area. According to the data of the Czech Statistical Office, as of 1 January 2015, the population was 24,850 inhabitants. For the share of economic subjects in chosen administrative areas 
of municipalities with extended powers on the territory of protected landscape areas, see Table 1 .

Table 1. The share of economic subjects in chosen administrative areas of municipalities with extended powers on the territory of protected landscape areas of Moravský Kras and Pálava, 2015 (Source: CZSO).

\begin{tabular}{|c|c|c|c|c|c|}
\hline \multirow[b]{2}{*}{$\begin{array}{l}\text { Share of Economic Subjects } \\
\text { Based on Chosen Sectors of } \\
\text { Economic Activities (\%) }\end{array}$} & \multicolumn{2}{|c|}{ Protected Landscape Area Pálava } & \multicolumn{3}{|c|}{ Protected Landscape Area Moravský Kras } \\
\hline & $\begin{array}{c}\text { Municipality } \\
\text { with Extended } \\
\text { Powers Břeclav }\end{array}$ & $\begin{array}{c}\text { Municipality } \\
\text { with Extended } \\
\text { Powers Mikulov }\end{array}$ & $\begin{array}{c}\text { Municipality } \\
\text { with Extended } \\
\text { Powers Blansko }\end{array}$ & $\begin{array}{l}\text { Municipality } \\
\text { with Extended } \\
\text { Powers Brno }\end{array}$ & $\begin{array}{l}\text { Municipality with } \\
\text { Extended Powers } \\
\text { Šlapanice }\end{array}$ \\
\hline Agriculture, Forestry, and Fishing & 7.6 & 10.6 & 4.1 & 1.8 & 4.1 \\
\hline Industry total & 12.2 & 13.8 & 16.1 & 10.4 & 15.8 \\
\hline Construction & 11.2 & 15.3 & 11.2 & 8.6 & 12.0 \\
\hline $\begin{array}{l}\text { Retail, Accommodation, Meals } \\
\text { and Restaurant Services }\end{array}$ & 27.4 & 26.5 & 24.5 & 27.3 & 24.8 \\
\hline
\end{tabular}

The Pálava PLA (Pavlov Highlands) covers an area of $83 \mathrm{~km}^{2}$, making it one of the smallest PLAs in the Czech Republic [34]. Overall, 30\% of its area is covered by forests, mainly in Děvín and the eastern part of the territory, and 55\% is agricultural land [32] with traditional vineyards. It is a particularly valuable biogeographical site with thermophilic ecosystems of almost Mediterranean character. Floodplain forests, wetland meadows in the Dyje floodplain, and one of the last habitats of salinephilic vegetation-Slanisko Nesyt-increase the diversity of the area. The character of the landscape is completed by agriculturally used plots with the predominance of vineyards, and individual settlements with the privileged position of the historic town of Mikulov [35].

According to the data of the Czech Statistical Office, as of 1 January 2015, the population was 13,344 inhabitants in the 11 cadastral areas. From this number, more than half of the inhabitants live in the municipality Mikulov (7443). The number of inhabitants in the remaining municipalities does not exceed 1000, which makes this region a typical rural area.

\subsection{Data Collection and Analysis}

The data were collected in two stages (Figure 8). The first stage included the collection of material for the identification of key objections and comments that the stakeholders (representatives of municipalities, economic operators, and individual citizens) used to argue against the declaration of the Soutok PLA for fear of complications that the new nature protection scheme would bring. A total of 93 min of meetings of municipal councils, 86 newspaper articles and special reports from environmental bodies, 19 decisive stances of municipalities, and 49 stances of the economic operators concerned were collected from publicly available sources and databases of the municipalities concerned during the 2008-2013 negotiations. The documents were subsequently submitted to content analysis, with the help of which we determined and categorized the key arguments of the stakeholders. Content analysis represents one of the techniques of document analysis that aims to organize and reveal latent information in written materials. It is based on an objective, systematic, and quantitative description of the content of the communication [36]. For qualitative content analysis, we used Mayring's approach [37,38], working with coding criteria that are developed based on research questions and theoretical background, while categories are derived inductively from the collected material. Categories are also verified and refined in order to fit previously established criteria. When examining the content, content units and categories were identified first and then used to evaluate the negative arguments in the final analysis. During the coding and classification process, each part was supervised and discussed by the authors in order to achieve relevant results. Depending on the chosen methodology, inductive or deductive coding or both might be used. Inductive coding starts with a detailed analysis of sources (articles, concepts, themes, etc.) and is useful for strategies using grounded theory. On the other hand, deductive coding works with a set of keywords, specific themes, and ideas, followed by indicating whether these 
are mentioned in the sources [39]. It enabled us to determine both the quantity of text expression (amount and frequency) and also the quality of new themes. Using deductive category application, the sources are analyzed according to a coding framework, and we can use different techniques: formal and content structuring, typifying, and scaling structuring [40]. For our study, we used a combination of inductive and deductive coding approaches. Generally, we can sum up deductive-inductive coding process into two steps. In the first step, we developed deductive categories, as mentioned above, and in the second step, we developed inductive categories for the analysis and the interpretation of new aspects and themes.

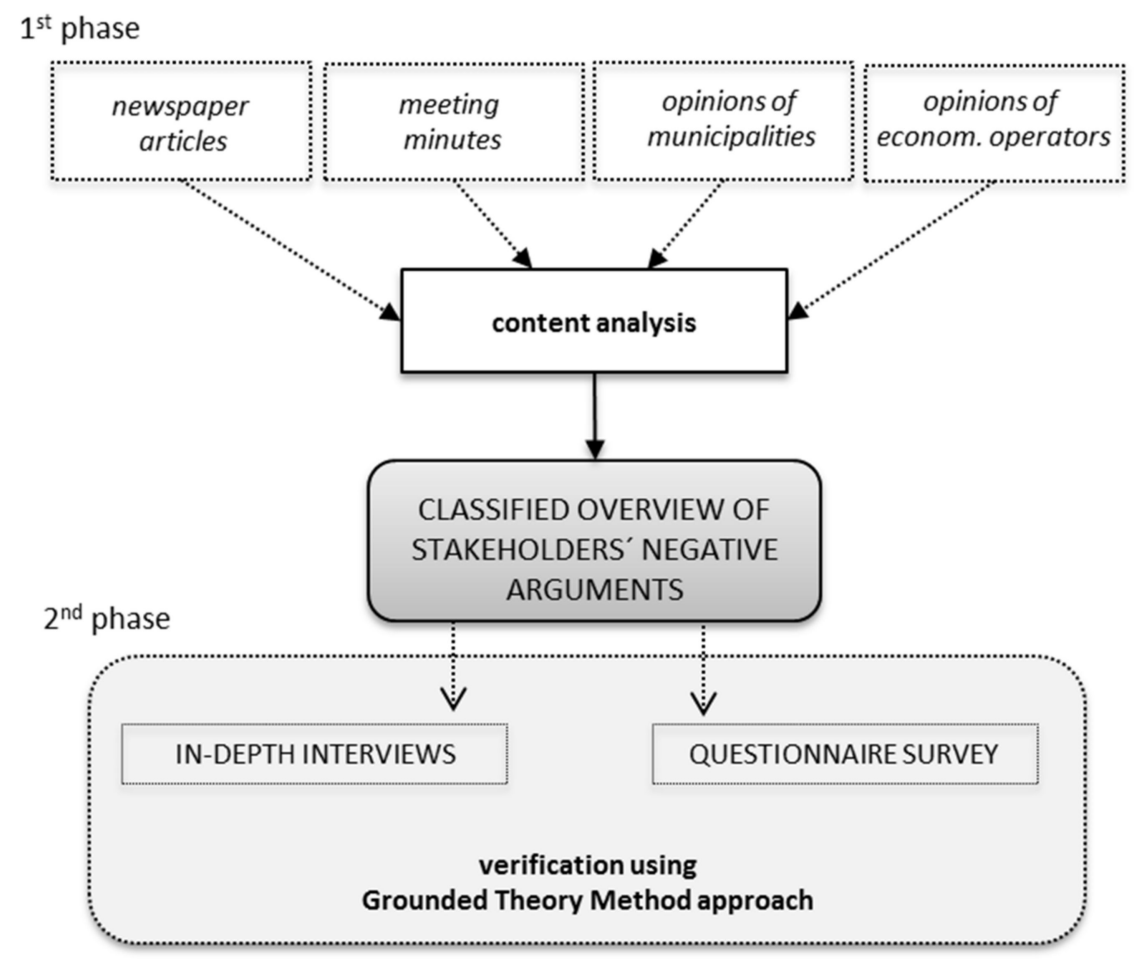

Figure 8. Methodological framework.

In this study, we used NVivo 11 software to conduct the content analysis. NVivo offers researchers the possibility to import various types of raw data (text files, audio and video files, and images), and although it can run automatically, we used a software-assisted approach and checked the data processing by reviewing the word list, removing irrelevant words and rerunning the query until the created proposed model (with parent nodes and child nodes) fit the best to present the findings [41].

The second stage represented a confrontation of the negative arguments with the attitudes of the representatives of the municipalities located in the existing PLAs in the same region that have a similar or close subject of nature and landscape protection as the proposed Soutok PLA. These were the Moravian Karst PLA and the Pálava PLA. For these needs, materials for in-depth, semistructured, and open-ended interviews and questionnaires were assembled. Respondents for face-to-face interviews were chosen on the basis of the purpose-made selection method using the snowball technique, in which other respondents were recruited on recommendation from previous interviews. In each of the selected PLAs, we chose both mayors of municipalities situated on the outskirts, which are almost unaffected by tourism, and municipalities located near the most visited tourist destinations. Within the Moravian Karst PLA, these included the municipalities of Blansko, Kanice, Ostrov u Macochy, and Vilémovice, and in the case of the Pálava PLA, the municipalities of Dolní Věstonice, Pavlov, Přítluky, and Sedlec u Mikulova. Furthermore, interviews were conducted with the representatives of major forest owners-the School 
Forest Enterprise Masaryk Forest Křtiny (Křtiny, Czech Republic) and the Židlochovice Forest Enterprise (LZ), the managers of PLA administration involved and other economic operators (AGRO Měřín Agricultural Holding). A total of 17 structured interviews with a standardized list of questions lasting 45-60 min were conducted in 2017. The arguments concerning the restrictions on the residents and visitors were evaluated on the basis of a questionnaire survey carried out in the summer months of 2018, i.e., during the main tourist season. We used the theoretical sampling technique [42] to select the respondents who answered partial questions within the scope of the Likert scale while openly commenting on partial arguments. It is based on a process of data collection for generating theory whereby the analyst jointly collects codes and analyses data and decides what data to collect next and where to find them. For the questionnaire survey, we used structured questionnaires that we administered personally and we collected 200 questionnaires with a response rate of $80 \%$.

The methodological framework covered the first phase-investigation in the proposed Soutok PLA and the second phase-the verification within present PLA/LPAs Moravský Kras and Pálava (Figure 8).

The grounded theory method presented by Glaser and Straus [42] was used to evaluate the interview and questionnaire data. It is probably the most widely used approach in qualitative research [43]. By formulating a research question, it seeks to create theories firmly grounded in data, thus distinguishing itself from theories that are created in an intuitive or speculative manner. It is a method of data analysis and a comprehensive approach that governs the research process from finding a research question to publishing the resulting theory and its possible further development. We used this approach to discover the motives and hidden relations between the perception of negations caused by the declaration of the Soutok PLA. When applying this approach, we proceeded in the following steps: (1) creating concepts, (2) seeking theoretical relations between concepts, and (3) selecting a central concept and formulating the theory. When creating the concepts, we used open coding, then axial coding, and selective coding.

\section{Results}

Of the total number of 200 respondents, 108 women (54\%) and 92 men (46\%) participated in the questionnaire survey. The majority of respondents belonged to the age group of $18-39(40.5 \%), 67$ respondents (33.5\%) to the age group of $40-59$, and $26 \%$ of participants to the age group of over 60 . In terms of the highest educational attainment, the respondents were divided into almost equal groups. We addressed 48 persons (24\%) with lower-level secondary education and 71 persons (35.5\%) with an advanced level of secondary education, attested by a certificate of apprenticeship or a diploma. A total of $27 \%$ of those surveyed had completed tertiary vocational education and $13.5 \%$ university education. Moreover, 102 persons living in the municipalities extending to the Moravian Karst PLA or the Pálava PLA were set aside by a filter question. Of these, 54 respondents live in the Moravian Karst PLA municipalities and 48 in the Pálava PLA municipalities.

\subsection{Arguments against the Declaration of the Soutok PLA-Overview}

Although negotiations on the declaration of the Soutok PLA have been held several times, it has not been enforced mainly due to the constant resistance of local municipalities and residents, whose negative attitude persists. Using contact analysis of available documents, we created a categorization of the negative arguments (Table 2) that the stakeholders repeatedly used to express their disapproval of the declaration of PLA. Nevertheless, even the opponents of the proposal are aware of the extraordinary value of the area. However, they are still convinced that the conservation status is sufficient and that the PLA would increase bureaucracy and restrictions. Opponents of the project include all mayors of the municipalities concerned, Forests of the Czech Republic, s.p. (state enterprise) on behalf of the Židlochovice Forest Enterprise, which is the administrator of most forests in the area, and the representatives of the Lower Morava Biosphere Reserve. 


\subsection{Arguments against the Declaration of the Soutok PLA-Increase in Stakeholders' Restrictions \\ Mainly, the residents of the affected municipalities were concerned about the restric- tions on normal movement in the area of the proposed Soutok PLA. These doubts are based on past experience when the territory belonged to the border zone where entry was banned for 40 years. The residents were therefore afraid of further bans and restrictions that, in their words, the PLA status would bring.}

Table 2. Objections and comments of stakeholders from the area concerned on the declaration of the Soutok PLA, own processing.

\begin{tabular}{|c|c|c|c|}
\hline Category & Unit & Description & Status/Relevance \\
\hline \multirow{7}{*}{ limitations } & $\begin{array}{l}\text { entry into and movement } \\
\text { in PLA }\end{array}$ & $\begin{array}{c}\text { residents' concerns over restrictions on entry and free } \\
\text { movement based on Section } 26 \text { of Act No. 114/1992 Sb., } \\
\text { on nature and landscape protection [44] }\end{array}$ & Not confirmed \\
\hline & $\begin{array}{l}\text { agricultural and forestery } \\
\text { production }\end{array}$ & $\begin{array}{l}\text { restrictions on agricultural and forestry production } \\
\text { resulting from Act No. 114/1992 Sb., on nature and } \\
\text { landscape protection [44] }\end{array}$ & Confirmed \\
\hline & ship transportation & $\begin{array}{l}\text { restrictions/termination of boat cruises on the Chateau } \\
\text { Pond and on the Morava river from Břeclav to Janův hrad }\end{array}$ & Irrelevant \\
\hline & & alienation of the residents in relation to the protected area & \\
\hline & compromised identity & $\begin{array}{l}\text { as a result of various prohibitions and restrictions, } \\
\text { disregard of regional and local needs and customs }\end{array}$ & Not confirmed \\
\hline & constructions & $\begin{array}{l}\text { intervention of officials in built-up parts of the area in } \\
\text { connection with the appearance of buildings and their } \\
\text { color design }\end{array}$ & Confirmed \\
\hline & bike trails construction & $\begin{array}{l}\text { ban on the construction of new asphalt bike trails after the } \\
\text { declaration of PLA; preservation of the existing trails is } \\
\text { not guaranteed }\end{array}$ & Not confirmed \\
\hline \multirow{5}{*}{$\begin{array}{c}\text { regional } \\
\text { development }\end{array}$} & construction closure & $\begin{array}{l}\text { restricted building work that would hamper the } \\
\text { development of municipalities thus leading to } \\
\text { depopulation and, most of all, the outflow of business } \\
\text { operators }\end{array}$ & Confirmed \\
\hline & $\begin{array}{l}\text { slowing/stopping } \\
\text { regional development }\end{array}$ & $\begin{array}{l}\text { fear that the municipalities will be gripped by the } \\
\text { protected areas without having a possibility to change the } \\
\text { master plan toward the expansion of built-up areas }\end{array}$ & Not confirmed \\
\hline & $\begin{array}{l}\text { decline in cross-border } \\
\text { cooperation }\end{array}$ & $\begin{array}{l}\text { negative impact on cross-border cooperation, e.g., } \\
\text { impossibility to build a footbridge across the Dyje river to } \\
\text { the Austrian municipality of Rabensburg }\end{array}$ & $\begin{array}{l}\text { Not documented. } \\
\text { Estimate: Not } \\
\text { confirmed }\end{array}$ \\
\hline & decline in tourism & $\begin{array}{l}\text { restricted development of tourism related to the } \\
\text { restrictions on the movement of people in PLA }\end{array}$ & Not confirmed \\
\hline & loss of job opportunities & $\begin{array}{l}\text { loss of job opportunities, especially in agriculture and } \\
\text { forestry that employ high numbers of people }\end{array}$ & Not confirmed \\
\hline \multirow{5}{*}{ economy } & decline in property prices & $\begin{array}{l}\text { concerns over the decline of land and real estate prices } \\
\text { due to regional development limits caused by the } \\
\text { declaration of PLA }\end{array}$ & Not confirmed \\
\hline & $\begin{array}{l}\text { decrease in the number of } \\
\text { small and medium-sized } \\
\text { businesses }\end{array}$ & $\begin{array}{c}\text { constraints to business development caused by limited } \\
\text { construction of technical infrastructure and civic resulting } \\
\text { from already low purchasing power of residents in } \\
\text { rural areas }\end{array}$ & Not confirmed \\
\hline & & under Act No. 114/1992 Sb. [44] mining of minerals in & \\
\hline & $\begin{array}{l}\text { reduction in } \\
\text { municipality income }\end{array}$ & $\begin{array}{l}\text { PLA zone } 1 \text { is prohibited, which will lead to a reduction in } \\
\text { the present extraction of oil, natural gas, and gravel sand } \\
\text { by private companies and thus to a reduction in the } \\
\text { income of the municipalities }\end{array}$ & Not confirmed \\
\hline & $\begin{array}{l}\text { increase in investments } \\
\text { connected with the } \\
\text { declaration of PLA }\end{array}$ & $\begin{array}{l}\text { the state does not provide any compensation for the } \\
\text { increase in investment caused by the protection }\end{array}$ & Not confirmed \\
\hline
\end{tabular}


Table 2. Cont

\begin{tabular}{|c|c|c|c|}
\hline Category & Unit & Description & Status/Relevance \\
\hline \multirow{4}{*}{$\begin{array}{l}\text { environmental } \\
\text { protection }\end{array}$} & $\begin{array}{l}\text { insufficient environmental } \\
\text { management plan }\end{array}$ & $\begin{array}{l}\text { the management plan is not drawn up pursuant to Section } \\
1 \text { of Decree No. } 80 / 2008 \text { Sb., on management plans, } \\
\text { designation and registration of areas protected under the } \\
\text { Nature and Landscape Protection Act }\end{array}$ & Not confirmed \\
\hline & $\begin{array}{l}\text { complications in } \\
\text { adopting FMP }\end{array}$ & $\begin{array}{l}\text { complications in drawing up the forest management plan } \\
\text { (FMP) mean restrictions on harvesting forest in the area of } \\
\text { interest and designing FMP that will primarily satisfy the } \\
\text { Agency for Nature Conservation and } \\
\text { Landscape Protection }\end{array}$ & Confirmed \\
\hline & $\begin{array}{l}\text { sufficient conservation } \\
\text { status }\end{array}$ & $\begin{array}{l}\text { the proposed area currently belongs to the Natura } 2000 \\
\text { network, there is a biosphere reserve, a UNESCO site, and } \\
\text { several small special protection areas that provide local } \\
\text { protection, so general protection is unnecessary }\end{array}$ & Not confirmed \\
\hline & our work, our care & $\begin{array}{l}\text { the current state of the area is an achievement of forest } \\
\text { managers from the Židlochovice Forest Enterprise, who } \\
\text { have been farming here for several generations }\end{array}$ & Not confirmed \\
\hline \multirow{2}{*}{$\begin{array}{l}\text { public } \\
\text { administration } \\
\text { and self- } \\
\text { government }\end{array}$} & $\begin{array}{l}\text { complications in } \\
\text { municipal } \\
\text { self-government }\end{array}$ & $\begin{array}{l}\text { the nature conservation authority with competence for the } \\
\text { territory directly in the PLA will be the PLA } \\
\text { administration and not the municipal authority with } \\
\text { enlarged jurisdiction or the regional authority, which will } \\
\text { complicate the submission of permit applications }\end{array}$ & Not confirmed \\
\hline & lack of information & $\begin{array}{c}\text { the Ministry of the Environment provided incomplete and } \\
\text { biased information about the declaration process of the } \\
\text { Soutok PLA }\end{array}$ & Not confirmed \\
\hline
\end{tabular}

Timber production and terrain conditions of forests (slopes, field accessibility) play an important role in understanding the conflicts between nature conservation and forest management. Floodplain forests of the proposed Soutok PLA represent the most productive forest ecosystems in the Czech Republic.

In the short term, the introduction of close to nature management may partially increase the cost of forest management, but the use of natural processes in forests brings a significant financial benefit in the long term [45]. In forest management, the use of forests should not bring just a short-term economic benefit. The widespread use of natural processes in forestry practice has a profound and long-term biological impact on the prosperity of forest ecosystems and thus the economy of their management.

Research has revealed that the status of PLA is not related to the reduced attractiveness of the area. Overall, 127 respondents (63.5\%) find areas outside large PLAs as attractive as national parks and PLAs themselves, and 70 respondents $(35 \%)$ find large protected areas more attractive. The majority of respondents (73\%) would be equally interested in the site even before the declaration. Most of them argued that "the declaration will not change the area in any way" and that "the site is either interesting or not, and this is not related to the PLA status." Furthermore, 26\% of the respondents will find the site more attractive because "there had to be a reason for the declaration" or "we will get better information about the area" and "the site will be better mapped." Only two of the respondents would find the site less attractive due to the fact that there will be a "less interesting nature" and also because these areas are "supervised," which seemed to be a limiting factor to them.

Representatives of municipal authorities unanimously agreed that certain rules for the shape of houses, colors of roofs, etc. are defined. However, not all respondents consider this to be a limitation. The most frequent limitation they mentioned was the duty to build gable roofs with red to brown burnt tiles and the impossibility to have dormers and balconies. Overall, $73.5 \%$ of participants did not feel restricted in the construction of the house. 
3.3. Arguments against the Declaration of the Soutok PLA-Negative Impact on the Development of the Region

Successful and sustainable development of the region is guaranteed by a well-designed master plan and balanced use of the potential of the area. In addition, the layout and land use are bound by generally applicable territorial limits. The responses of municipality mayors to the question of restrictions on construction in PLA are different and each of them sees restrictions from a different perspective. An important factor is also the location of the built-up part of the municipality in relation to the PLA. The Soutok PLA has been designed so that it does not extend to the built-up area. The proposal even featured a possible bypass of the city of Břeclav, when the area needed for the construction of new buildings was excluded from the PLA proposal in order to avoid potential conflict situations. The mayors of municipalities in current protected landscape areas do not think that PLAs limit the development of municipalities. In their words, entrepreneurs do not register offices in these municipalities as PLAs do not allow the construction of logistics centers or large development projects. However, this does not mean that the declaration of PLA is responsible for the declining number of small and medium-sized businesses. At the European level, there is a continuous need to strengthen relations between the environment, regional development, and regional planning. It is crucial to take into consideration the territorial impact on environmental planning, especially in the areas of planning and management of protected areas, water resources, soil erosion, or localization of dangerous and highly polluting substances, which are closely related to the impact on the landscape. The key concern should be the mobilization of the inner potential of municipalities in the form of brownfield revitalization rather than an extensive spatial extension. Similarly, the presence of PLA was not found to be a restriction on cross-border cooperation. Instead, the mayors emphasized the language barrier to be the main constraint.

An important question in the field of tourism is to what extent visitors affect the phenomena for which protection was declared. Any applicable restrictions are established in order to protect the phenomena that are destroyed by an onslaught of tourists. These are prohibitions and orders to guide tourists toward sustainable tourism so that there is still something to protect in the next decades. However, the interviews with the mayors showed that the municipalities are trying to develop tourism and attract tourists to other less well-known areas of the PLAs. Based on the research, the assumption of job losses related to the declaration of the PLA was not confirmed.

\subsection{Arguments against the Declaration of the Soutok PLA-Economic Risks}

Given the fact that PLAs were declared several decades ago, it is impossible to find out whether and how the declaration of PLA was reflected in the price of land. Comparing prices inside and outside PLAs seems to be a possible starting point, but it is very problematic since many more factors affect the price than just the PLA. Thus, mere price comparison cannot be considered a relevant methodology. For the above-given reasons, the exact land price movements cannot be determined. However, it is possible to point out low market intensity within the PLA, with few sales and offers made in comparison with the neighborhoods. Thus, only a fraction of what is sold outside is sold inside PLAs. Personal interviews showed that the respondents could not assess whether and how the land price had changed, precisely because the PLAs were declared a long time ago. Only one mayor pointed out that, in his opinion, the land inside the PLA was virtually unsaleable because of land use restrictions. An important argument for the municipalities in the proposed Soutok PLA was the possibility of extracting oil, natural gas, and gravel sand from which businesses contribute to the municipal budget. Partial objectives of the Moravian Karst PLA administration include a ban on further mining activities - not even in close proximity (currently only one surface limestone quarry is active), prevention of the establishment of new mineral deposits, and prevention of the declaration of new mining areas and support for restoration projects with maximum use of natural processes. This mention thus confirms the concern over the impossibility of mining in the newly declared PLA. On the other hand, 
the extraction of oil and natural gas does not take place on the surface in large mining areas but rather on spots. Real estate tax may pose another problem for the municipal budget. The land included in PLA zone 1 [46] is also exempt from real estate tax. Thus, municipalities lose part of the cadastral territory to this tax, which is otherwise fully paid to the municipality in whose territory the property is located [47]. It was often mentioned that nature conservation means increased investments, which must be paid from the municipal budget, but the state does not offer any compensation for them. However, municipality representatives mentioned that they can apply for subsidies, which in turn will relieve the municipal budget. It is precisely because of the location in the protected landscape area that the municipality is either awarded extra points for the location or receives a subsidy that can cover up to $100 \%$ of eligible costs. Interviews with representatives of municipalities clearly showed that nature conservation in the form of PLA does not mean an increase in investments for municipalities.

\subsection{Environmental Protection}

All existing territories in the Czech Republic have been cocreated or influenced by human beings and for their long-term functioning and biodiversity conservation other human interventions are usually necessary [48]. Although forest managers cannot be denied their share of the current state of forests in the area of the proposed Soutok PLA, the representative of the Židlochovice Forest Enterprise pointed out that the priorities and objectives of nature and landscape conservation are contradictory to their interests and thus incompatible. The Židlochovice Forest Enterprise prefers the production function of the forest that brings them an economic benefit. In contrast, nature conservation authorities try to prevent the loss of forest stands and promote sustainable forest management.

The PLA management plan can be understood as a tool for prescribing restrictions that are not binding on natural persons and legal entities, but it is a binding document for forest holdings and regional planning. Interviews with the representatives of the Moravian Karst PLA and the Pálava PLA reveal a contrast between the participation of local government representatives in the process of drawing up management plans in the localities of interest. While the Pálava PLA administration gives the mayors the final version of the document to look at and any comments are discussed at the Ministry of the Environment, the Moravian Karst PLA administration and the representatives of the municipalities discuss the document at an early stage when the document is being drawn up so the municipality representatives' comments can be considered almost immediately during discussions. The comment of the mayors of municipalities affected by the declaration of the Soutok PLA stems from the insufficient elaboration of the management plan, especially the missing chapters, when the management plan for the proposed Soutok PLA contained only the part dealing with nature protection and human activities affecting the state of nature and landscape. However, it is not common practice to draw up these documents before the PLA is declared.

The most frequent argument against the declaration of the proposed Soutok PLA was that the current protection of the site in question is adequate and the existing care in the form of small-sized specially protected areas and the Lower Morava Biosphere Reserve is sufficient. The basic problem of this argumentation is that small-sized specially protected areas cover only a small part of the proposed site (about $0.94 \%$ ). Furthermore, the Lower Morava Biosphere Reserve, as the only one of the biosphere reserves in the Czech Republic, is not subject to nature conservation authorities since it is largely situated outside of the large-sized specially protected area (with the exception of the part extending to the Pálava PLA), and it is also the only one represented by a nongovernmental organization. This model of governance is unique because, until now, the management of Czech biosphere reserves has always been associated with the performance of the administration of one of the bodies of the Ministry of the Environment (either a protected landscape area or a national park). The founders are the Czech Union for Nature Conservation, Forests of the Czech Republic, s.p. (state enterprise), MND, a.s. (Moravian Oil Mines), the Ministry 
of the Environment, and the District Chamber of Commerce Břeclav. Except for the Ministry of the Environment, all the founding bodies were opposed to the declaration of the Soutok PLA. In the meantime, the existing environmental protection allows promoting objectives that damage the environment, which means that it cannot be described as sufficient. Forest management, which is currently incompatible with nature and landscape protection (e.g., wide areas of regeneration blocks, using of exotic productive species game management with a long-time history of planting non-native walnut Juglans nigra L.), can also be classified as a fundamental problem that the existing protection of the site does not deal with. Another major change was the regulation of rivers (including the construction of the Nové Mlýny dams, built in the 1970s and 1980s), which meant a significant reduction in the length of their streams and strangling meanders. It had an impact on the entire floodplain forest ecosystem, which now needs to be artificially flooded. The problem also arises of the possible migration of animals to be protected. Managing such a vast territory by way of contractual agreements would only lead to fragmentation of the territory, ineffective management of protection, and an increase in administrative steps.

\subsection{Public Administration and Self-Government}

The problem of providing incomplete and unilateral information can be described as information asymmetry. The question of communication with the mayors and entities in the affected areas permeated the entire interview.

When efforts were made to declare the Soutok PLA, the opponents also referred to the poor reputation of nature conservation authorities. In their words, the breakthrough moment was the declaration of the Natura 2000 network, which was announced without any previous communication with local authorities. At the same time, the opinions of the mayors whose municipalities belong to the Pálava PLA were also influenced by this fact. Nature and landscape conservation cannot be taken as a strictly prescribed fact, but the general public must be involved in this process too. Residents' foreknowledge and participation in decision making on events in municipalities and their immediate surroundings is an essential part of a democratic society based on the coordination of actions and satisfaction of the entities concerned. It is therefore essential that citizens themselves get involved and submit their proposals and comments. After all, they form an inseparable part of protected areas, and they know best what pitfalls they bring and what problems need to be solved.

Mayors of municipalities affected by the intention to declare the Soutok PLA often stated that PLA brings complication in exercising state administration and self-government. The mayors of municipalities do not find any restrictions caused by the existence of PLA that would limit them in the performance of administrative duties. The situation is similar in the Pálava PLA where the mayors see complications limited to a minimum, and only in the area of construction activity. Municipalities are obliged to include the conditions for future construction activity, which are based on the requirements for nature and landscape conservation, in the master plan documentation. The restrictions are more significant in municipalities with a big part of a cadastral territory or built-up area in PLA. In the case of the Soutok PLA, there is no need for these restrictions since it is defined and delineated outside of the area suitable for construction activity. The mayors also stated that they had no competencies other than the mayors of municipalities outside of the PLA.

The position of local governments should not change even after the PLA is declared. According to the Ministry of the Environment, the only fundamental change will be that the nature conservation authority with competence for the area lying directly in the PLA will be the PLA administration and not the municipality with extended competence or the regional authority. Compared to the current situation when residents need part of the statement from a municipality with extended competence and part from a regional authority, this represents a considerable relief. 


\section{Discussion}

The declaration of protected areas is a frequently discussed and controversial topic since the present society considers nature conservation to be a very restrictive instrument [49]. The general opinion of the society is that conservationists considerably restrict or directly prohibit the alternative use of sites regardless of the changing reality. In some cases, the objectives of the protection are only possible in small scattered locations connected by narrow corridors. According to Chamblee et al. [50], spatial fragmentation of protected areas can bring fewer benefits than the preservation of a large area. In their research, McDonald et al. [51] also confirm the more traditional view that larger areas are more supportive of the protection of sites and enable comprehensive management. It can be argued that in the case of the proposed Soutok PLA protection in the form of large-sized protected areas is preferable. This claim is primarily based on the fact that the proposed PLA should protect the largest complex of floodplain forests in the Czech Republic covering a total area of $139 \mathrm{~km}^{2}$.

According to Dwyer et al. [52], tourism activities in the region are demonstrated by economic benefits when income and investments are transferred from richer and more developed areas to poorer and less developed areas. The overall aim of "environmentally friendly" tourism should be to achieve a situation in which the benefits generated significantly exceed the losses incurred as a result of its existence [53]. An increase in seasonal jobs can be expected in many municipalities, especially in accommodation and catering facilities. This conclusion is supported by Hall [54] or Kadiyali and Kosová [55], who identify protected areas as an important factor in the regional development of the municipalities concerned. When comparing alternative land use, it is impossible to say precisely which of the options is more economically advantageous for the region since the value of nature is immeasurable. However, to express its value, there is, for example, the concept of ecosystem services, which treats ecosystem functions as services [56] that provide a number of benefits for human well-being [49]. Many of these services can then be expressed by the economic value that is derived from the cost of artificial provisions of these services $[56,57]$. Although these services are increasingly considered by policymakers in the field of environmental management [58], they are not considered by the general public when deciding on land management [49]. Recognition of ecosystem services as assets of economic and social value can contribute to promoting nature conservation and making more responsible decisions when addressing development projects [59]. Nevertheless, by comparing the resulting value it can be concluded that sustainable management in a given ecosystem is more economically advantageous than its transformation motivated by unilateral land use [45]. Mainly American studies deal with the development of land prices immediately after the declaration of the protected landscape area $[50,60]$. These studies concluded that the price of land in the immediate vicinity of protected areas tends to rise. However, studies conducted in the United States cannot be considered entirely relevant for the central European region since the land price reflects a number of factors, and a different valuation system may operate on another continent.

The process of establishing and administering a protected area must involve the society, in particular local residents, whose perception of the protected area influences the attitude, actions, and interaction of the residents with the area. Lack of knowledge and attitudes of the main stakeholders can lead to incorrect selection of methods for territory management $[25,61,62]$ and influencing the views of the general public by important players [25]. Stakeholders are thus a key factor for successful site management [23,63]. It is known that a positive attitude toward the protected area has a strong influence on its successful management. However, stakeholders' attitudes and perceptions are not implemented by nature conservation authorities in the decision-making process [64]. Primarily, local stakeholders' socioeconomic factors (age, gender, education, ethnic origin, place of residence, etc.) are examined since they influence their perception of and attitude to protected areas. Only a small part of the study is devoted to their perception of the protected area before its declaration $[10,65]$. In line with changing societal preferences, 
environmental consideration has been increasing in forestry in most of the developed world [66]. This has naturally caused conflicts between the traditional utilitarian and environmental interests, e.g., as expressed through the ideological clashes between the defenders of forest owners' rights and the advocates of weightier public interference [66].

Findings from Ward et al. [67] study have highlighted a number of challenges related to PA comanagement as follows: (1) any reduction in ES access is likely to create a short-term opportunity cost. These costs need to be explicitly recognized and livelihood interventions should be designed with this in mind; (2) the diversity of cultural and social values given to livelihood activities relating to ES use needs to be carefully incorporated rather than considering them as conservation or sustainability issues; and (3) community-level PA institutions need to ensure that all household types and social divisions are represented in order to prevent worsening existing or creating new inequalities [67]. Accepting these findings will be crucial for the successful establishment of the Soutok Protected Landscape Area, its acceptance by local stakeholders, and the use of ecosystem services for their quality of life.

\section{Conclusions}

The declaration of large-sized protected areas in the Czech Republic mostly takes the form of a top-down approach, and thus, it often leads to controversial and emotional debates among politicians, nature conservationists, residents, and stakeholders. Sometimes, the negotiations are held so long that the intention to declare a protected area is abandoned in the end. For example, this was the case of the proposed Soutok PLA. However, it should be noted that the existence of large-sized protected areas is not a barrier to all regional development, and it is even considered to be an engine of the local economy in some countries. Still, it is necessary to differentiate suitable management methods and activities that ensure the development of the area while maintaining its natural and landscape values according to the zones of graded protection. It is essential that socioeconomic development goes hand in hand with successful landscape care and protection. Be it forestry or agricultural activity, there are certain limits that have to be respected. Farmers can claim financial compensation for the loss sustained, which is paid to them but not always in full. Forest management is closely linked with the forest management plan, for which the PLA management plan is binding and must be governed by it. Therefore, mining requirements must be considered; otherwise, a positive opinion will not be issued. In forest management, this should not be a short-term economic benefit from the use of forests. The widespread use of natural processes in forestry practice has a profound and long-term biological effect on the prosperity of forest ecosystems and hence the economy of their management.

The research highlighted the importance of communication between municipality representatives, stakeholders, and residents, on the one hand, and representatives of protected areas, on the other. From the results, it is obvious that communication is the basis for successful cooperation because mutual coordination of steps is necessary for the smooth functioning and coexistence of nature conservation and regional development. Unfortunately, common practice shows that nature conservation authorities often act in a superior manner and do not give local government representatives a choice. This creates a generally negative image of nature conservation. Perfect foreknowledge of the entities on both sides is essential, both for the functioning of nature conservation and for mutual trust necessary for good cooperation.

The research refuted or did not confirm most of the arguments of stakeholders against the declaration of the PLA. Reasoned comments either stemmed from other legislation or did not have a negative impact on regional or municipal development. The approach of nature protection officials toward municipalities and communication with them is perceived as a very important aspect. The negative perception of nature protection and state administration is a serious consequence of a possible unfriendly approach. 
The general main problem to be solved is environmental awareness and education, which, for representatives of farmers and owners and municipalities, is especially about the natural benefits, the intrinsic value of nature, and the vulnerability of ecosystems; for nature conservation representatives, this is especially in the area of communication with other stakeholder groups. Both of these tools need to be used for a long time, but also immediately.

Author Contributions: Conceptualization, J.S., A.R. and M.B.; methodology, J.S., A.R. and M.B.; validation, J.S. and A.R.; formal analysis, A.R.; investigation, M.B.; resources, M.B.; data curation, A.R.; writing-original draft preparation, M.B. and A.R.; writing-review and editing, J.S. and A.R.; visualization, M.B. and A.R.; supervision, J.S.; project administration, J.S.; funding acquisition, J.S. All authors have read and agreed to the published version of the manuscript.

Funding: The research was funded by the Internal Grant Agency Faculty of regional development and international studies, Mendel University in Brno, project No. 16/2015-Selected environmental tools as regional development factors and EEA Grants, Grant Number EHP-CZ02-OV-1-032-2015 "Raising awareness and publicity of the importance of forest functions in the landscape and nearnatural watercourses in urban areas as a part of basin ecosystem services."

Institutional Review Board Statement: Not applicable.

Informed Consent Statement: Not applicable.

Conflicts of Interest: The authors declare no conflict of interest.

\section{References}

1. Cardillo, M.; Mace, G.M.; Gittleman, J.L.; Purvis, A. Latent extinction risk and the future battlegrounds of mammal conser-vation. Proc. Natl. Acad. Sci. USA 2006, 103, 4157-4161. [CrossRef] [PubMed]

2. Leroux, S.J.; Krawchuk, M.A.; Schmiegelow, F.; Cumming, S.G.; Lisgo, K.; Anderson, L.G.; Petkova, M. Global protected areas and IUCN designations: Do the categories match the conditions? Biol. Conserv. 2010, 143, 609-616. [CrossRef]

3. Stolton, S.; Dudley, N. Arguments for Protected Areas: Multiple Benefits for Conservation and Use; Earthscan: London, UK, $2010 ;$ p. 273.

4. Jones, N.; McGinlay, J.; Dimitrakopoulos, P.G. Improving social impact assessment of protected areas: A review of the literature and directions for future research. Environ. Impact Assess. Rev. 2017, 64, 1-7. [CrossRef]

5. Blondet, M.; De Koning, J.; Borrass, L.; Ferranti, F.; Geitzenauer, M.; Weiss, G.; Turnhout, E.; Winkel, G. Participation in the implementation of Natura 2000: A comparative study of six EU member states. Land Use Policy 2017, 66, 346-355. [CrossRef]

6. Karanth, K.K.; Naughton-Treves, L.; DeFries, R.; Gopalaswamy, A.M. Living with Wildlife and Mitigating Conflicts Around Three Indian Protected Areas. Environ. Manag. 2013, 52, 1320-1332. [CrossRef]

7. Rakotonarivo, O.S.; Jacobsen, J.B.; Poudyal, M.; Rasoamanana, A.; Hockley, N. Estimating welfare impacts where property rights are contested: Methodological and policy implications. Land Use Policy 2018, 70, 71-83. [CrossRef]

8. Zorondo-Rodríguez, F.; Díaz, M.; Simonetti-Grez, G.; Simonetti, J.A. Why would new protected areas be accepted or rejected by the public?: Lessons from an ex-ante evaluation of the new Patagonia Park Network in Chile. Land Use Policy 2019, 89, 104248. [CrossRef]

9. Barbić, A.; Udovć, A.; Medved, A. Protection of the environment and biodiversity for sustainable future of rural areas: The case of planned Regional park Trnovski gozd, Slovenia. Sociol. Sela 2004, 42, 4.

10. Winter, S.J.; Esler, K.J.; Kidd, M. An index to measure the conservation attitudes of landowners towards Overbeg Coastal Renosterveld, a critically endangered vegetation type in the Cape Floral Kingdom, South Africa. Biol. Conserv. 2005, 126, 383-394. [CrossRef]

11. Nastran, M. Why does nobody ask us? Impacts on local perception of a protected area in designation, Slovenia. Land Use Policy 2015, 46, 38-49. [CrossRef]

12. Conrad, E.; Fazey, I.; Christie, M.; Galdies, C. Choosing landscapes for protection: Comparing expert and public views in Gozo, Malta. Landsc. Urban Plan. 2019, 191, 103621. [CrossRef]

13. Allendorf, T.D. A framework for the park-people relationship: Insights from protected areas in Nepal and Myanmar. Int. J. Sustain. Dev. World Ecol. 2010, 17, 417-422. [CrossRef]

14. MacKenzie, C.A.; Salerno, J.; Hartter, J.; Chapman, C.A.; Reyna, R.; Tumusiime, D.M.; Drake, M. Changing perceptions of protected area benefits and problems around Kibale National Park, Uganda. J. Environ. Manag. 2017, 200, 217-228. [CrossRef]

15. Pullin, A.S.; Bangpan, M.; Dalrymple, S.E.; Dickson, K.; Haddaway, N.R.; Healey, J.R.; Hauari, H.; Hockley, N.; Jones, J.P.G.; Knight, T.M.; et al. Human well-being impacts of terrestrial protected areas. Environ. Évid. 2013, 2, 19. [CrossRef]

16. de Lange, E.; Woodhouse, E.; Milner-Gulland, E.J. Approaches used to evaluate the social impacts of protected areas. Conserv. Lett. 2016, 9, 327-333. [CrossRef] 
17. Kaplan-Hallam, M.; Bennett, N.J. Adaptive social impact management for conservation and environmental management. Conserv. Biol. 2018, 32, 304-314. [CrossRef]

18. Schmitz, M.; Matos, D.; de Aranzabal, I.; Ruiz-Labourdette, D.; Pineda, F. Effects of a protected area on land-use dynamics and socioeconomic development of local populations. Biol. Conserv. 2012, 149, 122-135. [CrossRef]

19. Bennett, N.J. Using perceptions as evidence to improve conservation and environmental management. Conserv. Biol. 2016, 30, 582-592. [CrossRef]

20. Abukari, H.; Mwalyosi, R.B. Local communities' perceptions about the impact of protected areas on livelihoods and community development. Glob. Ecol. Conserv. 2020, 22, e00909. [CrossRef]

21. Ciocănea, C.M.; Sorescu, C.; Ianoşi, M.; Bagrinovschi, V. Assessing Public Perception on Protected Areas in Iron Gates Natural Park. Procedia Environ. Sci. 2016, 32, 70-79. [CrossRef]

22. Buta, N.; Holland, S.M.; Kaplanidou, K. Local communities and protected areas: The mediating role of place attachment for pro-environmental civic engagement. J. Outdoor Recreat. Tour. 2014, 5, 1-10. [CrossRef]

23. Arnberger, A.; Eder, R.; Allex, B.; Sterl, P.; Burns, R.C. Relationships between national-park affinity and attitudes towards protected area management of visitors to the Gesaeuse National Park, Austria. For. Policy Econ. 2012, 19, 48-55. [CrossRef]

24. Trakolis, D. Local people's perceptions of planning and management issues in Prespes Lakes National Park, Greece. J. Environ. Manag. 2001, 61, 227-241. [CrossRef]

25. Allendorf, T.D.; Smith, J.L.; Anderson, D.H. Residents' perceptions of Royal Bardia National Park, Nepal. Landsc. Urban Plan. 2007, 82, 33-40. [CrossRef]

26. Spiteri, A.; Nepalz, S.K. Incentive-Based Conservation Programs in Developing Countries: A Review of Some Key Issues and Suggestions for Improvements. Environ. Manag. 2005, 37, 1-14. [CrossRef]

27. Apostolopoulou, E.; Drakou, E.G.; Pediaditi, K. Participation in the management of Greek Natura 2000 sites: Evidence from a cross-level analysis. J. Environ. Manag. 2012, 113, 308-318. [CrossRef] [PubMed]

28. Rojas-Briales, E. Socio-economics of nature protection policies in the perspective of the implementation of Natura 2000 Network: The Spanish case. Forestry 2000, 73, 199-207. [CrossRef]

29. Nastran, M.; Pirnat, J. Stakeholder Participation in Planning of the Protected Natural Areas: Slovenia. Sociol. Prost. 2012, 19350, 141-164. [CrossRef]

30. Schneider, J.; Ruda, A.; Kalasová, Ž.; Paletto, A. The Forest Stakeholders' Perception towards the NATURA 2000 Network in the Czech Republic. Forests 2020, 11, 491. [CrossRef]

31. Vyskot, I.; Kupec, P.; Schneider, J.; Klimánek, M. Optimalisation of forest management-model area of Special Protection Area of Soutok-Tvrdonicko, Forest Enterprise Zidlochovice, Forests of the Czech Republic. In Biodiversity and Target Management of Floodplain Forests in Morava River Basin, 1st ed.; Machar, I., Ed.; Nakladatelství Univerzity Palackého v Olomouci: Olomouc, Czech Republic, 2010; pp. 172-181. ISBN 978-80-244-2530-6.

32. Mackovčin, P.; Jatiová, M.; Demek, J.; Slavík, P. Brněnsko. In Chráněná Území ČR, Svazek IX; Ekocentrum Brno a VÚKOZ; Mackovčin, P., Sedláček, M., Eds.; AOPK ČR: Praha, Czech Republic, 2007.

33. PLA Moravský Kras. Management Plan for PLA Moravský Kras for Period 2019-2028; PLA Moravský Kras: Brno, Czech Republic, 2017.

34. Bárta, F.; Němec, J.; Pojer, F. Krajina v České Republice; Consult: Praha, Czech Republic, 2007; p. 399.

35. PLA Pálava. Management Plan for PLA Pálava for Period 2016-2025. 2015. Available online: https:// palava.ochranaprirody.cz/ ochrana-prirody/plan-pece-chko-palava/ (accessed on 26 July 2019).

36. Mayring, P. Qualitative content analysis. In A Companion to Qualitative Research; Flick, U., von Kardoff, E., Steinke, I., Eds.; Sage: London, UK, 2004; pp. 266-269.

37. Mayring, P. Qualitative Inhaltsanalyse. Grundlagen und Techniken; Beltz: Weinheim, Germany, 1983.

38. Mayring, P. Qualitative Content Analysis. Forum Qualitative Sozialforschung; Forum: Qualitative Social Research 1. 2000. Available online: https:/ /www.qualitative-research.net/index.php/fqs/article/view/1089b (accessed on 26 July 2019 ).

39. Bazeley, P. Qualitative Data Analysis with NVivo, 2nd ed.; Sage: Thousand Oaks, CA, USA, 2007.

40. Mayring, P. Qualitative Content Analysis: Theoretical Foundation, Basic Procedures and Software Solution. 2014. Available online: https://www.researchgate.net/publication/266859800_Qualitative_content_analysis_-_theoretical_foundation_basic_ procedures_and_software_solution (accessed on 26 July 2019).

41. Richards, T. An intellectual history of NUD*IST and NVivo. Int. J. Soc. Res. Methodol. 2002, 5, 199-214. [CrossRef]

42. Glaser, B.G.; Strauss, A.L. The Discovery of Grounded Theory: Strategies for Qualitative Research; 1999. Available online: http:/ / www.sxf.uevora.pt/wp-content/uploads/2013/03/Glaser_1967.pdf (accessed on 26 July 2019).

43. Bryant, A.; Charmaz, K. Grounded Theory in Historical Perspective: An Epistemological Account. In The SAGE Handbook of Grounded Theory; Bryant, A., Charmaz, K., Eds.; SAGE: London, UK, 2007; pp. 31-57.

44. Act, no. 114/1992 Coll. on Nature Conservation and Landscape Protection. Sbírka zákonů České republiky. 1992.

45. Košulič, M. Cesta k Přírodě Blízkému Hospodářskému Lesu; FSC Česká Republika-Forest Stewardship Council: Brno, Czech Republic, 2010; p. 452.

46. Act, no. 338/1992 Coll. on the Tax on Immovables. Sbírka zákonů České republiky. 1992.

47. Act, no. 243/2000 Coll. on Budget Allocation of Taxes. Sbírka zákonů České republiky. 2000. 
48. Abelairas-Etxebarria, P.; Astrokiza, I. Farmland prices and land-use changes in periurban protected natural areas. Land Use Policy 2012, 29, 674-683. [CrossRef]

49. Seják, J. Principy a metody oceňování životního prostředí. Zivotn. Prostr. 2002, 36, 10-13.

50. Chamblee, J.F.; Colwell, P.F.; Dehring, C.A.; Depken, C.A. The Effect of Conservation Activity on Surrounding Land Prices. Land Econ. 2011, 87, 453-472. [CrossRef]

51. McDonald, R.I.; Yuan-Farrell, C.; Fievet, C.; Moeller, M.; Kareiva, P.; Foster, D.; Gragson, T.; Kinzig, A.; Kuby, L.; Redman, C. Estimating the Effect of Protected Lands on the Development and Conservation of Their Surroundings. Conserv. Biol. 2007, 21, 1526-1536. [CrossRef]

52. Dwyer, L.; Forsyth, P.; Dwyer, W. Tourism Economics and Policy; Channel View Publications: Bristol, UK, 2010 ; Volume 5, p. 880.

53. Christofakis, M. Strategic Options for Tourism Impacts on Local Sustainability: A Conceptual Approach. Local Econ. 2010, 25, 586-598. [CrossRef]

54. Hall, C.M. Tourism—Rethinking the Social Science of Mobility; Pearson Prentice Hall: London, UK, 2005.

55. Kadiyali, V.; Kosová, R. Inter-industry employmeent spillovers from tourism inflows. Reg. Sci. Urban Econ. 2013, 43, $272-281$. [CrossRef]

56. Pithart, D.; Křováková, K.; Žaloudík, J.; Dostál, T.; Valentová, J.; Valenta, P.; Weyskrabová, J.; Dušek, J. Ecosystem services of natural floodplain segment-Lužnice River, Czech Republic. In Flood Recovery, Innovation and Response II; Wrachien, D., Proverbs, D., Brebbia, C.A., Mambretti, S., Eds.; WIT Press: Southampton, UK, 2010; pp. 129-143.

57. De Groot, R.S.; Alkemade, R.; Braat, L.; Hein, L.; Willemen, L. Challenges in integrating the concept of ecosystem services and values in landscape planning, management and decision making. Ecol. Complex. 2010, 7, 260-272. [CrossRef]

58. Boithias, L.; Terrado, M.; Corominas, L.; Ziv, G.; Kumar, V.; Marqués, M.; Schuhmacher, M.; Acuña, V. Analysis of the un-certainty in the monetary valuation of ecosystem services-A case study at the river basin scale. Sci. Total Environ. 2016, 543, 683-690. [CrossRef]

59. Fei, L.; Shuwen, Z.; Jiuchun, Y.; Kun, B.; Qing, W.; Junmei, T.; Liping, C. The effects of population density changes on ecosystem services value: A case study in Western Jilin, China. Ecol. Indic. 2016, 61, 328-337. [CrossRef]

60. Geoghegan, J. The value of open spaces in residental land use. Land Use Policy 2002, 19, 91-97. [CrossRef]

61. Reed, M.S. Stakeholder participation for environmental management: A literature review. Biol. Conserv. 2008, 141, $2417-2431$. [CrossRef]

62. King, B.; Peralvo, M. Coupling Community Heterogeneity and Perceptions of Conservation in Rural South Africa. Hum. Ecol. 2010, 38, 265-281. [CrossRef]

63. Arnberger, A.; Schoissengeier, R. The other side of the border: Austrian local residents' attitudes towards the neighbouring Czech Šmava National Park. J. Nat. Conserv. 2012, 20, 135-143. [CrossRef]

64. Struhsaker, T.T.; Struhsaker, P.J.; Siex, K.S. Conserving Africa's rain forests: Problems in protected areas and possible solutions. Biol. Conserv. 2005, 123, 45-54. [CrossRef]

65. Barbić, A.; Udovć, A. Protection of the Environment and Biodiversity for Sustainable Future of Rural Areas: The Case of Planned Regional Park Trnovski Gozd, Slovenia; Discussion Papers 18886; CEESA-Central and Eastern European Sustainable Agriculture International Research Project: Trnovski Gozd, Slovenia, 2003; Available online: http:/ /hdl.handle.net/10419/22296 (accessed on 26 July 2019).

66. Brukas, V.; Stanislovaitis, A.; Kavaliauskas, M.; Gaižutis, A. Protecting or destructing? Local perceptions of environmental consideration in Lithuanian forestry. Land Use Policy 2018, 79, 1014-1023. [CrossRef]

67. Ward, C.; Stringer, L.; Holmes, G. Changing governance, changing inequalities: Protected area co-management and access to forest ecosystem services: A Madagascar case study. Ecosyst. Serv. 2018, 30, 137-148. [CrossRef] 